\title{
Innovation through Coopetition: Future Directions and New Challenges
}

\author{
Valentina Della Corte \\ Department of Economics, Management, Institutions, University of Naples Federico II, 80122 Napoli, Italy; \\ valentina.dellacorte@unina.it
}

Received: 11 September 2018; Accepted: 18 September 2018; Published: 2 October 2018

\begin{abstract}
The paper focuses on the topic of the relationship between coopetition and innovation as well as on their impact on competitive advantage. Before getting to the central issue, a literature review on the topic of coopetition is carried out, in order to catch the existing gaps as well as to single out the paths for future development on the topic. Starting with a bibliometric analysis, the research then focuses on the contents of the contemporary literature, analyzing the main approaches internationally developed. The hint is to study the relationship between innovation and coopetition (in terms of antecedents) and then the impact of innovation-based coopetition or of coopetition-based innovation on firm performance.
\end{abstract}

Keywords: coopetition; innovation; competitive advantage

\section{Introduction: Context and Research Questions}

In the global and digital era, business models are significantly less stable and changing [1] and, consequently, the related competitive and collaborating dynamics difficult to analyze and even to forecast. In such framework, it is interesting and helpful to study the role of coopetition in fostering firm's innovation and its relative implications.

Coopetition and coopetitive strategies are usually ascribed to the intuitive work of Brandeburger and Nalebuff [2] who, in a very systematic way, start considering inter-firm relationships according to game theory. More specifically, these authors propose a framework where, even when partners are competitors, they may have some complementary opportunities. This awareness of parties allows to avoid destructive strategic behaviors towards contexts of win-win conditions. In this logic, these scholars developed the PARTS model, in which every single player (P) can be both competitor and complementor. With this double function, the actor can produce Added Value (A), getting a wider slice of the pie by being in the game, if behaving in respect of the rules (R) and using the right Tactics (T) when anticipating reactions to actions, according to the prisoner's dilemma. This dilemma implies that actors can maximizes their profits when the advantages of cooperation overcome those from competition or defection [3]. This successful process favors a "variable-plus-sum game" rather than a "zero-sum" one [4]. Coopetion can take to "win- win-win" situations when all parties earn from the relationships more than when they just compete (zero-sum game) or cooperate with individual behaviors (plus-sum game).

The main literature on the topic concentrates on:

(1) the typologies of coopetitive situations (dyadic rather than multiple, like in business networks, or horizontal rather than vertical [5]);

(2) the process (spontaneous rather than guided also through top-down initiatives of Institutional partners);

(3) the types of firms (for example, with reference to small and medium enterprises-SMEs- [6-8]); 
(4) the intensity of competition and collaboration ([9-11]);

(5) the impacts of coopetition, both in terms of the nature of relationships (economic rather than social, for example) and with reference to the inter-firm relationship rather than to the single participating actor ([12]). As regards the intangible effects of coopetition, there are still very interesting aspects, not adequately studied, especially in terms of ex-ante vs ex-post evaluations when engaging into a collaboration.

In spite of its undoubtful interest, the literature on coopetition seems not to catch up the rapidly changing dynamics in firms' strategic behaviors.

Mostly, a huge amount of papers deals with contexts characterized by dominant partners (focal firms [13]). Over time, there have been some even weak attempts to extend the spectrum of the unit of analysis as well as of the main reasons that push firms to adopt this kind of strategy. Such attempts have been adopted within different perspectives (mainly in the fields of strategic management, competitive dynamics and business networks).

However, there are still several limitations in the scientific work on the issue.

Firstly, there is an overall set of fragmented contributions ([6,7,10-12,14,15]).

Secondly, most studies are focused on firm-to-firm relationships, that usually are started by larger firms or by a single firm with its network of suppliers/clients [16].

Besides, the majority of contributions describes the process without explaining when and why to coopete, if it is possible to gain sustainable competitive advantage through coopetition.

Theoretically, the topic can be studied with double lenses, that are resource-based theory $[17,18]$ and open innovation, considering also how the interaction of these two approaches in coopetition can foster innovation in a 4.0 industry perspective.

Both these theories are, in fact, in line with the concept of coopetition, considering that putting together complementarities can make markets grow even if there is, at the same time, competition in those markets [17].

In this paper, the research question is if the topic of innovation connected with coopetition is treated in the literature. To answer this research question, I propose a bibliometric analysis followed by a deep study of the main papers on the topic, in order to examine the links between innovation and coopetition as well as to outline the main future directions and new challenges on the issue.

\section{Theoretical Framework and Literature Review: Methods}

Literature production on coopetition has developed extensively in latest years.

I conducted a bibliometric analysis in order to focus the attention on the ongoing literature on the topic. This method is usually adopted to quantify literature production as well as to measure its main impact; however, it can be also very useful a conceptual analysis, as well as the main research dynamics on the issue $[10,19]$.

As known, biblometrix aims to describe how scientific disciplines and research fields are structured and evolve over time, getting to systemic adequate results.

The datasource was Clarivate Analytics Web of Science (http://apps.webofknowledge.com), which is the most important worldwide. I conducted the selection of both articles, reviews and proceedings' papers through the query: "coopetition" or "co-opetition" term included either in the title, or in the abstract or in the keywords of the studied articles. The research was strictly managed on the term coopetition or co-opetition because it is a very specific topic and yet inter-disciplinary so it was interesting to see the multiple points of view of the ongoing research on the topic. Works of the latest 20 years were selected also to study the evolution of the theory on the topic.

The analysis between 1996 and 2018 shows a concentrated production on more than 4 hundred papers, written by 840 authors with an average citation per article of 18.11 (Table 1). 
Table 1. Data on scientific production on the topic.

\begin{tabular}{lc}
\hline Documents & 430 \\
Sources (Journals, Books, etc.) & 232 \\
Keywords Plus (ID) & 816 \\
Author's Keywords (DE) & 1204 \\
Period & $1996-2018$ \\
Average citations per documents & 18.11 \\
\hline Authors & \\
Author Appearances & \\
Authors of single authored documents & 54 \\
Authors of multi authored documents & 786 \\
\hline Documents per Author & 0.512 \\
Authors per Document & 1.95 \\
Co-Authors per Documents & 2.44 \\
Collaboration Index & 2.21 \\
\hline
\end{tabular}

The highest numbers of papers were registered between 2013 and 2018 (Figure 1), thus confirming this is a rather new topic in its developments. The most cited papers are in Organization Science, Industrial Market Management, as well as International journals on small and medium enterprises, ICT, and venture capital (Table 2). The most productive countries are West countries (USA, France, Finland, UK), with a huge increase of papers in China and Taiwan: the topic has therefore started to develop also in Eastern countries (Figure 2).

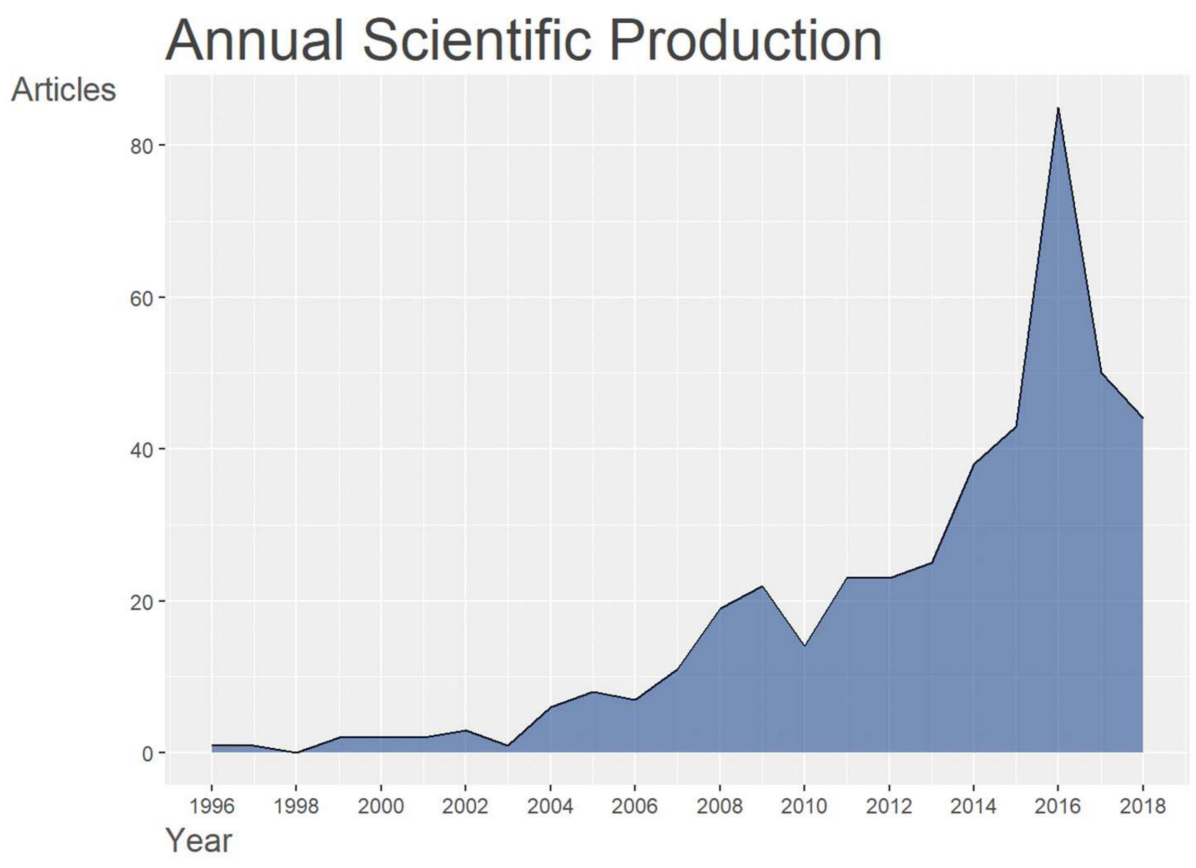

Figure 1. Annual scientific production.

Table 2. The most cited papers.

\begin{tabular}{lcc}
\hline Papers & Total Cit. & TC Per Year \\
\hline 1 TSAI WP, 2002, ORGAN SCI & 685 & 42.81 \\
2 BENGTSSON M, 2000, IND MARKET MANAG & 524 & 29.11 \\
3 LECHNER C, 2003, ENTREP REGION DEV & 310 & 20.67 \\
\hline
\end{tabular}


Table 2. Cont.

\begin{tabular}{lcc}
\hline Papers & Total Cit. & TC Per Year \\
\hline 4 CARAYANNIS EG, 2009, INT J TECHNOL MANAGE & 207 & 23.00 \\
5 GNYAWALI DR, 2011, RES POLICY & 199 & 28.43 \\
6 LECHNER C, 2006, J BUS VENTURING & 188 & 15.67 \\
7 GNYAWALI DR, 2009, J SMALL BUS MANAGE & 176 & 19.56 \\
8 LUO XM, 2006, J MARKETING & 162 & 13.50 \\
9 LUO YD, 2007, J WORLD BUS & 151 & 13.73 \\
10 RITALA P, 2009, TECHNOVATION & 144 & 16.00 \\
11 GNYAWALI DR, 2006, J MANAGE & 138 & 11.50 \\
12 LUO YD, 2009, ACAD MANAGE PERSPECT & 131 & 14.56 \\
13 QUINTANA-GARCIA C, 2004, TECHNOVATION & 125 & 8.93 \\
14 LUO YD, 2005, J WORLD BUS & 121 & 9.31 \\
15 CHEN MJ, 2008, J MANAGE INQUIRY & 114 & 11.40 \\
16 KETCHEN DJ, 2004, J MANAGE & 109 & 7.79 \\
17 MENTION AL, 2011, TECHNOVATION & 108 & 15.43 \\
18 BENGTSSON M, 2014, IND MARKET MANAG & 103 & 25.75 \\
19 WU ZH, 2010, J OPER MANAG & 102 & 12.75 \\
20 RITALA P, 2012, BRIT J MANAGE & 95 & 15.83 \\
\hline
\end{tabular}

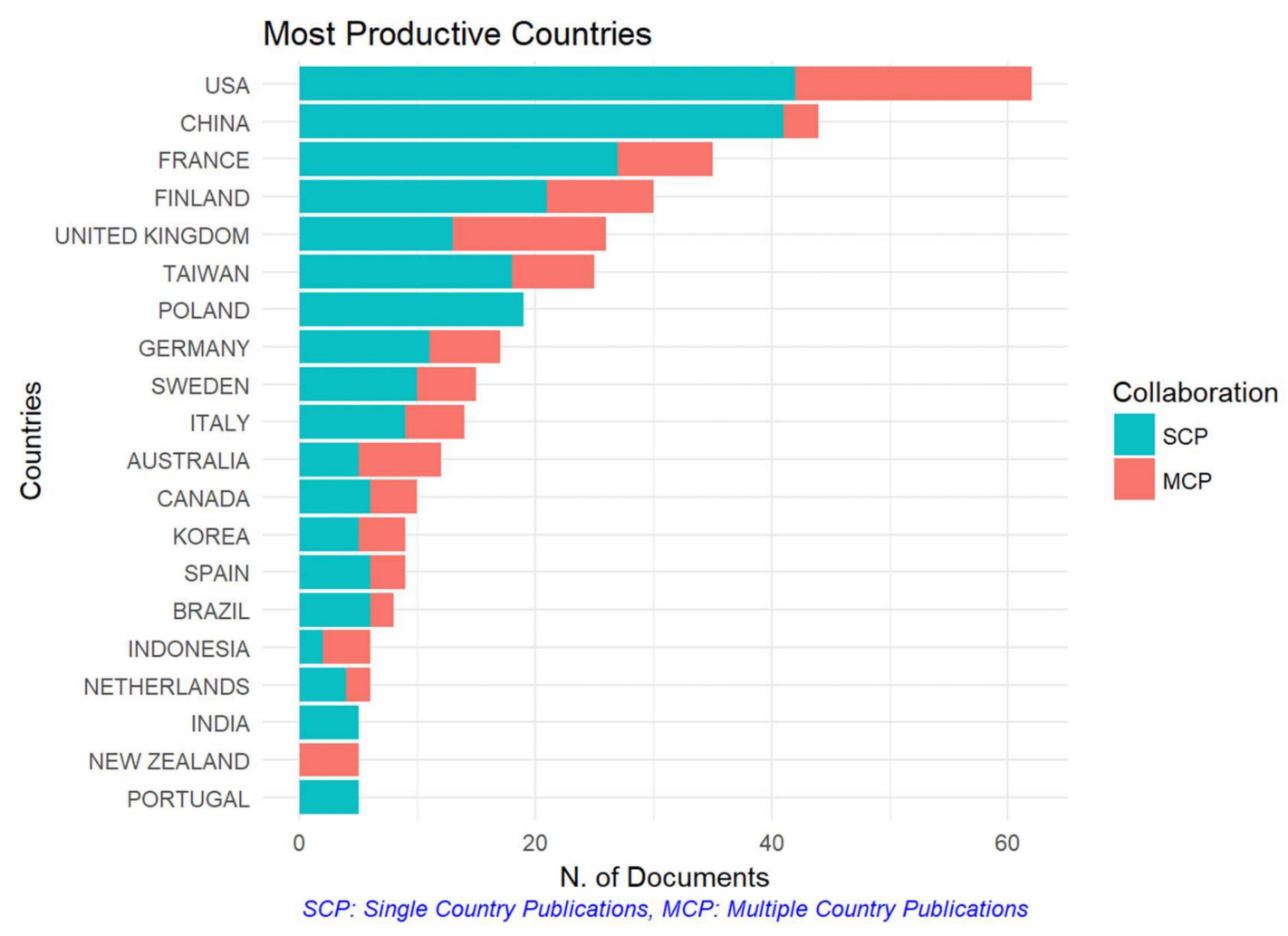

Figure 2. The most productive countries.

In order to pass to a content's analysis, the study of the co-word networks can be of extreme importance in order to better explore the main topics, both more important and more recent. This co-word analysis was conducted considering both the title and the abstract of the papers. Looking at the keywords' occurrences, I considered the association for 50 plots for the main references and got to a very interesting result: among the main words associated to coopetition, beside cooperation and competition, there is also the term "innovation", proving that there is an interest, in the literature, on this relationship (Figure 3). 


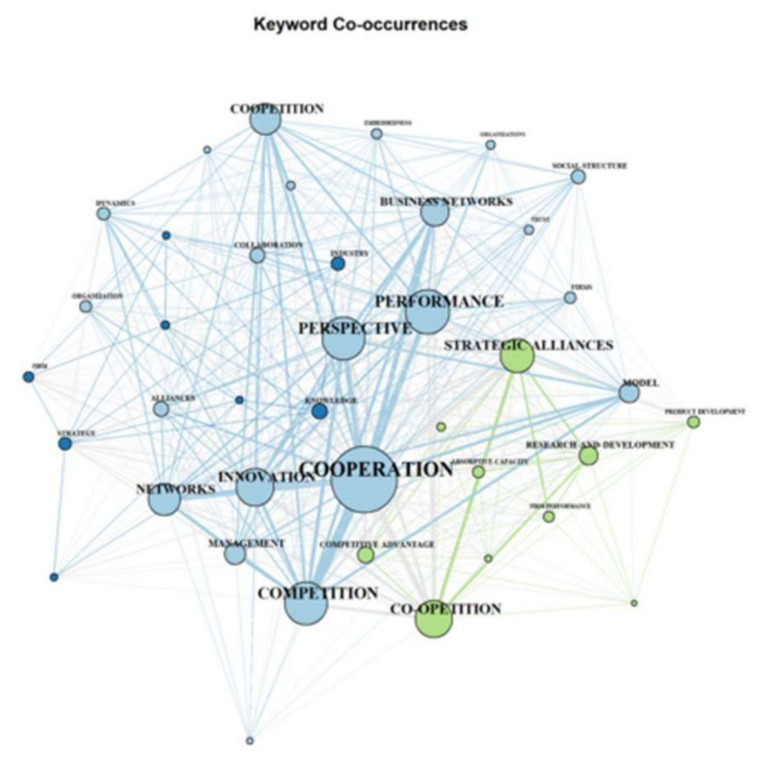

Figure 3. Co-word analysis through keyword co-occurrences.

From a strictly strategic perspective, the main reasons that have always fostered firms to cooperate are connected with their need for new resources and competences they do not possess (also for innovation purposes). Starting from this need, firms use their capacities to identify relevant actors in their own industries [3] and to classify the most profitable relationships to activate even between competitors, to both generate and sustain competitive advantage [20]. This is in line with resource-based theory perspective.

Stating that the concept of coopetition is still in the process of development, Bengsston and Kock [6] refine their definition of coopetition, considering the specificities and differences from the other inter-firm relationships and asserting that it is setting of a contextual competitive and cooperative interactions between actors, both in horizontal and in vertical relationships.

As shown in Table 3, Brandenburger and Nalebuff [3] define firms' propensity to cooperate and compete simultaneously as coopetition. At this stage, coopetition is strictly related to internal knowledge management and information processes [21]. In further contributions [8,10,22], the focus is on interfirm relationships since authors stress the attention on the possibility that cooperation and competition activities between firms can increase knowledge sharing. According to the definition of Bengtsson and Kock [23], coopetition is the firm-to firm relationship that, even if competing with each other, develop partnerships on some specific activities. At this further stage, literature mainly focuses on the nature as well as on the sources of coopetition and gives little importance to the benefits these relationships create.

Table 3. Main contributions on the definitions of coopetition.

\begin{tabular}{cl}
\hline & \multicolumn{1}{c}{ Main Authors } \\
\hline $\begin{array}{c}\text { Bradenburger } \\
\text { and Nalebuff } \\
\text { [23] }\end{array}$ & $\begin{array}{l}\text { "Co-opetition is a new way of thinking about business. Some people } \\
\text { see business entirely as competition. They think doing business is } \\
\text { waging war and assume they can't win unless somebody else loses. } \\
\text { Other people see business entirely as co-operation-teams and } \\
\text { partnerships. But business is both co-operation and competition" }\end{array}$ \\
$\begin{array}{l}\text { Bengtsson and } \\
\text { Kock [24] }\end{array}$ & $\begin{array}{l}\text { "In any specific relationship elements of both cooperation and } \\
\text { competition can be found, but one or the other of these elements can in } \\
\text { some cases be tacit. If both the elements of cooperation and competition } \\
\text { are visible, the relationship between the competitors is } \\
\text { named coopetition" }\end{array}$ \\
\hline
\end{tabular}


Table 3. Cont.

\begin{tabular}{|c|c|c|}
\hline \multicolumn{3}{|r|}{ Main Authors } \\
\hline $\begin{array}{l}\text { Lado, Boyd, } \\
\text { and Hanlon [20] }\end{array}$ & 1997 & $\begin{array}{l}\text { "Firms can generate economic rents and achieve superior, long-run } \\
\text { performance through simultaneous competition and cooperation" }\end{array}$ \\
\hline Soubeyran [25] & 2002 & $\begin{array}{l}\text { "When competitors cooperate there is a continuous tension between } \\
\text { competition and cooperation ... In practice this means that two firms } \\
\text { can cooperate within for example purchasing and service, } \\
\text { simultaneously as they compete within manufacturing and marketing } \\
\ldots \text { These firms are not solely competitors or rivals in a traditional sense, } \\
\text { but they are also partners who cooperate" }\end{array}$ \\
\hline $\begin{array}{l}\text { Levy, Loebecke, } \\
\text { Powell [8] }\end{array}$ & 2003 & $\begin{array}{l}\text { "Co-opetition entails sharing knowledge that may be a key source of } \\
\text { competitive advantage. Yet, the knowledge gained by cooperation may } \\
\text { also be used for competition. However, there is little investigation of } \\
\text { how this problem may be modelled and, hence, managed. A } \\
\text { game-theoretic framework for analyzing inter-organizational } \\
\text { knowledge sharing under co-opetition and guidelines for the } \\
\text { management of explicit knowledge predicated on coordination and } \\
\text { control theory has been proposed but remains untested" }\end{array}$ \\
\hline BarNir [26] & 2002 & "Simultaneous(ly) cooperative and competitive behavior" \\
\hline $\begin{array}{l}\text { Dagnino, } \\
\text { Padula [10] }\end{array}$ & 2007 & $\begin{array}{l}\text { "Coopetition is a matter of incomplete congruence of interests and } \\
\text { goals concerning firms' interdependence" }\end{array}$ \\
\hline Luo [5] & 2005 & $\begin{array}{l}\text { Coopetition is "to create a bigger business pie, while competing to } \\
\text { divide it up" }\end{array}$ \\
\hline $\begin{array}{l}\text { Eikerbokk, } \\
\text { Olsen [13] }\end{array}$ & 2005 & "Simultaneous cooperation and competition" \\
\hline $\begin{array}{l}\text { Gnyawali, He } \\
\text { and Madhavan } \\
\quad[7]\end{array}$ & 2008 & $\begin{array}{l}\text { "Coopetition affects firms' competitive behavior, resource asymmetries } \\
\text { in coopetitive networks may lead to different competitive actions" }\end{array}$ \\
\hline $\begin{array}{c}\text { Padula, } \\
\text { Dagnino [10] }\end{array}$ & 2007 & $\begin{array}{l}\text { Coopetition is "the intrusion of competition in a cooperative } \\
\text { game structure" }\end{array}$ \\
\hline Luo [27] & 2004 & $\begin{array}{l}\text { "Coopetition is the simultaneous competition and cooperation between } \\
\text { two or more rivals competing in global markets" }\end{array}$ \\
\hline Slywotzky [28] & 2007 & $\begin{array}{l}\text { "Coopetition emphasizes the mixed-motive nature of relationships in } \\
\text { which two or more parties can create value by complementing each } \\
\text { other's activity" }\end{array}$ \\
\hline $\begin{array}{l}\text { Wang and } \\
\text { Krakover [29] }\end{array}$ & 2008 & $\begin{array}{l}\text { "Manage the relationship between cooperation and competition, } \\
\text { individual benefits and common benefits in order to achieve success for } \\
\text { tourism destination and their individual businesses" }\end{array}$ \\
\hline Bengtsson [23] & 2010 & $\begin{array}{l}\text { "Coopetitive relationships offer the advantage of a combination of the } \\
\text { need to innovate in new areas as a result of competition while accessing } \\
\text { new resources as a consequence of cooperation" }\end{array}$ \\
\hline Gnyawali [30] & 2011 & $\begin{array}{l}\text { Coopetition consists in managing dyadic and horizontal supply chain } \\
\text { relations between suppliers "in order to avoid competitive forces from } \\
\text { prevailing or diminishing" }\end{array}$ \\
\hline Ritala [31] & 2012 & $\begin{array}{l}\text { Coopetition is "having a certain number of competitors in the total } \\
\text { portfolio of alliance partners-and on the business environments in } \\
\text { which such a strategy is successful" }\end{array}$ \\
\hline Hsieh et al. [32] & 2013 & $\begin{array}{l}\text { "Coopetition is a business strategy based on a combination of } \\
\text { cooperation and competition, derived from an understanding that } \\
\text { business competitors can benefit when they cooperate" }\end{array}$ \\
\hline $\begin{array}{c}\text { Park, } \\
\text { Srivastava, } \\
\text { Gnyawali [33] }\end{array}$ & 2014 & $\begin{array}{l}\text { Coopetition and firms' innovation performance, concept of balanced } \\
\text { coopetition (when competition is moderately high and cooperation } \\
\text { is high) }\end{array}$ \\
\hline Dahal [34] & 2014 & $\begin{array}{l}\text { Coopetition as a process-how cooperative interactions change as } \\
\text { competitors acquire new experiences from mutual cooperation and } \\
\text { their external environment changes }\end{array}$ \\
\hline
\end{tabular}


Table 3. Cont.

\begin{tabular}{|c|c|c|}
\hline \multicolumn{3}{|r|}{ Main Authors } \\
\hline $\mathrm{Wu}[35]$ & 2014 & $\begin{array}{l}\text { Dynamics of cooperation between competitive actors in R\&D } \\
\text { development, that can foster both product innovation, concentrating of } \\
\text { the implications of both firm specific capabilities and of external } \\
\text { linkages (with universities and research institutes) }\end{array}$ \\
\hline Ritala et al. [36] & 2014 & $\begin{array}{l}\text { Coopetition-based business models are important to put coopetitive } \\
\text { strategies into practice and how much value can be created and which } \\
\text { portion can be captured by the firm }\end{array}$ \\
\hline \multicolumn{3}{|r|}{ Other Sources } \\
\hline $\begin{array}{l}\text { Della Corte V., } \\
\text { Aria M. [4] }\end{array}$ & 2016 & $\begin{array}{l}\text { "Coopetition highlights the need to overcome the oversimplified } \\
\text { framework at the base of conventional approaches and proposes a } \\
\text { description of more complex market structures where cooperation and } \\
\text { competition merge together to form a new perspective. By widening } \\
\text { the conventional boundaries of the two more familiar categories of } \\
\text { competition and cooperation, coopetition challenges the traditional } \\
\text { framework addressing the surge of complexity of actors' roles, } \\
\text { strategies, objectives, processes and rent seeking behaviours" }\end{array}$ \\
\hline $\begin{array}{c}\text { Umachandram } \\
{[37]}\end{array}$ & 2018 & $\begin{array}{l}\text { A constructive tension where both competition and cooperation } \\
\text { between agents are pursued, contributing to their mutual benefit. } \\
\text { Coherent behavior within a system arises from the interplay of } \\
\text { competition and cooperation among the agents }\end{array}$ \\
\hline
\end{tabular}

Source: our elaboration.

Some works underline that coopetition is business-specific, in the sense that its configurations depend on the business setting, and is favoured by Information and Communication Technologies (ICT) that create new competitive scenarios [21]. The challenges of globalization and the new competitive scenario have led authors to investigate on one side the sources of coopetition and on the other its effects on competitive advantage. The main contributions on coopetition highlight that firms can decide to establish short- or long-term relationships with their competitors, both being a competitor and a partner at the same time. These reflections have opened the scenario to further contributions on the theme, focusing on the nature of the relationships between firms. There are, in fact, different situations that characterize actors' relationships on a territory.

The most recent contributions on coopetition highlight its importance as a business strategy according to which it is possible to generate higher results $[31,32,38]$.

According to the degree of coopetition, several scholars have dealt with the different types of interfirm relationships. Recalling a previous work of Easton et al. [39], Bengsston and Kock [24] state that the degree of coopetition can be measured considering the degree of cooperation as well as the distance (dependency) between competitors. This view recalls the type of relationships a firm can activate within a sector. Furthermore, they deal with horizontal and vertical relationships. In this sense, coopetition is an alternative to other types of relationships. Such contributions have led to some other reflections on the theme, identifying reciprocal and multipolar coopetition and analyzing the relationship between coopetition and collusion, underlining that when coopetition has advantages not only for the involved actors but also for the client, this is not the case of collusion and it is possible to get to a "win-win-win" setting [14].

The analyzed works show a certain attention to the relationships that can occur between large companies or between large and small firms, with particular reference to the studies on global competition contexts [27]. The empirical research on this issue is not largely developed and merely referred to the high-tech industry $[11,28,36]$. The most relevant examples in the field are the collaborative arrangements between Hewlett-Packard and Canon or the joint investments and the other collaborating activities between Sony and Samsung [28].

Studies on business networks [21] directs some reflections on the possibility for small firms to obtain greater benefits from the interactions with other actors, here including competitors. Starting 
from these points of view, coopetition becomes an interesting field of study with reference to the SMEs $[8,40]$, which of course are more fragile in coping with the risks and uncertainty of technological changes and R\&D activities [26,41]. Some studies, in fact, focus on coopetition in SMEs, identifying in the collaboration with competitors the possibility of generating economies of scale, risk management and resources' leverage [12]. These reflections are extremely true with reference to the tourism industry and the systemic approach $[25,29,42]$, typical of this industry. The definition that, in this wide range of situations, I adopt is the following [43,44]:

a firm which has some cooperation relationships with firms that are, at the same time, competitors in some other market (Dowling, Roering, Carlin $\mathcal{E}$ Wisnieski, 1996) or mainly in the same market.

Very interesting, in this reasoning, are the more recent contributions from Dahl [34], Wu at al. [45] and Ritala et al. [31], that open new horizons in the research on coopetition. Dahal concentrates on the process and therefore on the dynamics of the relationship over time. Wu studies the dynamics of cooperation between competitive actors in R\&D development, that can foster both product innovation, concentrating on the implications of both firm specific capabilities and external linkages (with universities and research institutes). Ritala et al. focus on the changes in business models and in their relative dynamics. These contributions better underline the implications of coopetition in firms' strategies and competitive settings.

According to what has been underlined before, coopetitive dynamics should have a more positive impact on performance. Considering recent contributions, those with empirical investigations are just a few [7] and therefore there is limited work on the impact of coopetition on performance; moreover, several studies underline how firms can reinforce their own resources and competitiveness through coopetition [30]. The real advantage for firms is that, even if competitors, they can generate higher value for the customer through collaborative paths [45] and/or reduce their own costs and risks by sharing their knowledge and resources, here including the possibility of making the firm's image and brand grow faster and more easily, as well as the opportunity to enter new markets [31]. However, as for the study of the impacts of coopetition, some works concentrate on firms' behaviors [7], others mainly on the intangible effects, here including trust and commitment [12] and paying less attention to economic performance. The reason can be traced in the fact that intangible effects of coopetition may produce greater value for the firms, according to the previous assumptions. This perspective opens up new horizons to the research on the issue.

Research Scope: Coopetition and Innovation

Firms' capacities of innovation are considered important factors in gaining and sustaining competitive advantage [46]. One of the aspects that seems to influence these dynamics a lot is coopetition intensity. There is a wide debate on the topic, since there are contributions [7] that assert that high levels of competition and cooperation enhance the level of innovation within the firm, others [23] focus on the possible difficulties in managing the relationships [30]. The specific interplay between the two even contradictory aspects and their impact on performance is starting to be studied. From this point of view, two main approaches have been developed.

On a side, there is the model described by [47] Brandenburger et al., that outlines four situations with different outcome implications:

1. The partnering coopetition type takes place in contexts characterized by high cooperation-share of common goals and interests-and low competition—little disagreements in strategies and market to serve.

2. The adapting coopetition type occurs in front of high cooperation-high competition situations. There is substantial incongruence in their individual approaches, but they cooperate owing to the following interconnections between their relative relationship-specific investments.

3. The isolating coopetition type corresponds to low cooperation-low competition situations in which the actors have not relevant relationships with just a weak connection [48]. 
4. The contending coopetition type corresponds to low cooperation-high competition situations, referred to situations of different goals, very weak connection and probable opportunistic behaviours $[49,50]$.

This study, however, especially with reference to the third situation, appears as more characterized by a prevailing opportunistic view of firm's behavior, giving a negative interpretation to the relationships of high competition and high cooperation. This specific situation is in fact even defined as "adapting", considering the constraints that push a firm to be in the relationships and not also the explicit strategic decision for an overall higher value creation.

Another interesting model is proposed by Park et al., 2014, concentrating on the impact of coopetition on innovation performance, trying to study the effects of parallel pursuits of both competitive and cooperative dynamics, with their relative intensity.

These authors consider the possible combinations of coopetition and collaboration, singling out the following situations:

1. Weak levels of both competition and cooperation determine a weak coopetition; strong cooperation and competition generate cooperation-dominant coopetition; strong competition determines competition-dominant coopetition if the cooperation is weak and balanced strong coopetition if also cooperation is strong.

2. The intensity of cooperation of a focal firm with its partners has a positive relationship with the firm's coopetition-based innovation up to a certain level, after which the benefits of cooperation start declining;

3. The effect of balanced strong coopetition on the focal firm's coopetition-based innovation is greater than the competition-based innovation and the cooperation-based innovation.

In their analysis, these scholars consider coopetition-based innovation as dependent on both alliances, on the access to the other party's knowledge and on creating private benefits in the partner's knowledge domains.

A more recent study [4,37], gets to similar conclusions, even if with a wider theoretical model, since it encompasses an open resource-based perspective, in analyzing the impact of coopetition on sustainable competitive advantage. This is done by singling out specific variables, for each dimension and valuating also their linkages, through three main indexes: two complex indexes for coopetition and collaboration respectively and a complex index of coopetition that corresponds to the average mean of collaboration and competition indexes. This study reveals interesting for a number of reasons: 1. it considers not just dyadic relationships but network relationships without the necessary presence of a focal firm and this changes the unit of analysis significantly; 2. it takes into account numerous variables for each dimension-collaboration and competition; it links these aspects to competitive advantage, thus confirming that situations of high competition and high collaboration are more open to innovation and this impacts on both firm and network performance.

In all these contributions then it emerges that the balanced combination of competition and collaboration, especially if high, can generate innovation and therefore favor competitive advantage.

Thinking, more specifically, about open innovation $[2,45]$ it is interesting to study in which aspects of open innovation coopetition can mainly impact: on this regard, open innovation has essentially a technological soul, an organizational one and a systemic one (which refers to the relationship between the firm and other external actors). The first two dimensions refer to firm specific capabilities and, therefore, to the more competitive side of the issue; the latter takes into account the possible cooperation a firm can set up and develop, thanks to its relational capabilities.

This view also implies the consideration of the individual versus relational capabilities that, in coopetitive contexts, can favour innovation and therefore competitive advantage. In this framework, however, the sources of competitive advantage are multiple and depend on the firm's capacity to manage all these factors around, not necessarily owned or controlled by the firm itself. 
Today the firm is a core of a network of interactions with different actors at more levels, of different sizes and strategic approaches. This determines several possible paths of development in a very complex network of relationships of different nature. It also requires a total revision of the business model of the firm itself. In order to better clarify the actual ongoing process. Thein firm interacts with competitors and, in this case, innovation is fostered by competition and is linked to the intensity of the competition itself. On the other side, innovation can also be the output of interfirm collaboration, according to the relational view [46] and thus generating rents through cooperation. The issue is if coopetition context can be more favorable to open innovation, since it implies a double perspective: firms compete using innovation as a determinant tool on a side and, on the other, they cooperate when the level of desired innovation needs complementary resources and therefore requires a collaborative initiative. If, however, there are all these aspects that can influence the overall set of relationships, then the open innovation business model is necessary. This in fact allows to consider that the general framework can be different for large firms compared with small and medium enterprises: in the former case, the model is basically concentrated on the focal firm with its connections; in the latter, the model is usually also more community-based and clan system-based. The key aspect is to study the process of knowledge sharing and exchange because the entire process is determined by the will/reluctance of the firm towards knowledge sharing with other actors [51,52].

\section{Conclusions}

Coopetition and its relationship with innovation is still an under-explored issue. Of course, this paper considers mainly top-cited papers, thus not including maybe insightful scientific papers that have not just attained high volume of citations because they are more recent or because they are not in lists of Web of Science.

In the overall work, all published papers are considered, apart from the citations; in the analysis, a higher attention has been given to the most cited ones, in order to better verify the stage of the main advances in the theory. However, also more recent relevant pieces have been considered, like the latest publications in the Journal of Management, 2018. Besides, this paper is a first result of an ongoing process and, in the future steps of the research, an extension and monitoring of the publications on the issue will be done. As underlined in a recent publication [40], there is still a superficial conceptualization of the simultaneity of cooperation and competition processes as well as scarce theory on the properties of coopetition and how this influences performance. However, this recent article represents a conceptual effort in reinforcing the path towards a theory on coopetition.

Such considerations bring the studies on innovation and of coopetition towards some areas of convergence and overlapping, since nowadays we cannot help thinking about the different types of relations of the firm in its competitive setting and general environment, through multiple interactions also favoured by the most recent advances in open innovation (industry 4.0, with all its connected tools [37] Umachandram et al.). This opens up the horizons, both of academics and decision makers, towards a new idea of doing business, much more unstructured but as simplest as possible and efficient. From this point of view, new competencies area required in the firms, new human resources profiles, new suggestions on if, when and how to share knowledge with others. Besides, the main result of this paper is also the relationship between coopetition and innovation: do we have to discuss about coopetition-based innovation or rather of innovation-based coopetition. The hint is that These are the real challenges for the very close future and I think our community has a great responsibility on the issue that, if well examined and studied, can really foster the entire economy towards new interesting and unthought opportunities.

Funding: The publishing fee of this paper was supported by the DGIST R\&D Program of the Ministry of Science, Technology and ICT (DGIST-18-IT-01).

Conflicts of Interest: The authors declare no conflict of interest. 


\section{References}

1. Siderska, J.; Jadaan, K.S. Cloud manufacturing: A service-oriented manufacturing paradigm. A review paper. Eng. Manag. Prod. Serv. 2018, 10, 22-31. [CrossRef]

2. Yun, J.J. Business Model Design Compass; Springer: Singapore, 2017.

3. Brandenburger, A.; Nalebuff, B. Coopetition; Doubleday: New York, NY, USA, 1996.

4. Della Corte, V.; Aria, M. Coopetition and sustainable competitive advantage. The case of tourist destinations. Tour. Manag. 2016, 54, 524-540. [CrossRef]

5. Luo, Y. Toward coopetition within a multinational enterprise: A perspective from foreign subsidiaries. J. World Bus. 2005, 40, 71-90. [CrossRef]

6. Bengsston, M.; Kock, S. Coopetitiond-Quo vadis? Past accomplishments and future challenges. Ind. Mark. Manag. 2014, 43, 180-188.

7. Gnyawali, D.R.; He, J.; Madhavan, R. Co-opetition: Promises and challenges. In 21st Century Management: A Reference Handbook; Sage Publications: Thousand Oaks, CA, USA, 2008; pp. 386-398.

8. Levy, M.; Loebbecke, C.; Powell, P. SMEs, co-opetition and knowledge sharing: The role of information systems1. Eur. J. Inf. Syst. 2003, 12, 3-17. [CrossRef]

9. Damayanti, M.; Scott, N.; Ruhanen, L. A review of the concept of coopetition: Application in tourism. In CAUTHE 2013: Tourism and Global Change: On the Edge of Something Big; Fountain, J., Moore, K., Eds.; Lincoln University: Christchurch, New Zealand, 2013; pp. 135-145.

10. Padula, G.; Dagnino, G. Untangling the rise of coopetition: The intrusion of competition in a cooperative game structure. Int. Stud. Manag. Org. 2007, 37, 32-52. [CrossRef]

11. Yamy, S.; Castaldo, S.; Dagnino, G.B.; Le Roy, F. Coopetition Winning Strategies for the 21st Future; Elgar Publishing: Cheltenham, UK, 2010.

12. Morris, M.; Kocak, A.; Ozer, A. Coopetition as a small business strategy: Implications for performance. J. Small Bus. Strategy 2007, 18, 35-55.

13. Eikebrokk, T.R.; Olsen, D.H. Co-opetition and e-business success in SMEs: An empirical investigation of European SMEs. In Proceedings of the 2005 HICSS'05 38th Annual Hawaii International Conference on System Sciences, Big Island, HI, USA, 6 January 2005.

14. Walley, K. Coopetition: An introduction to the subject and an agenda for research. Int. Stud. Manag. Org. 2007, 37, 11-31. [CrossRef]

15. Yang, S.; Fang, S.; Fang, S.; Chou, C. Knowledge exchange and knowledge protection in interorganizational learning: The ambidexterity perspective. Ind. Mark. Manag. 2014, 43, 346-358. [CrossRef]

16. Yoon, S.; Jeong, S. Effects to implement the open-innovation coordinative strategies between manufacturer and retailer in reverse supply chain. J. Open Innov. Technol. Mark. Complex. 2017, 3, 2. [CrossRef]

17. Barney, J. Strategic factor markets: Expectations, luck, and business strategy. Manag. Sci. 1986, 32, 1223-1370. [CrossRef]

18. Barney, J.B. The resource-based theory of the firm. Organ. Sci. 1996, 7, 469-479. [CrossRef]

19. Glińska, E.; Siemieniako, E. Binge drinking in relation to services-Bibliometric analysis of scientific research directions. Eng. Manag. Prod. Serv. 2018, 10, 45-54. [CrossRef]

20. Lado, A.; Boyd, N.; Hanlon, S. Competition, cooperation, and the search for economic rents: A syncretic model. Acad. Manag. Rev. 1997, 22, 110-141. [CrossRef]

21. Loebecke, C.; Van Fanema, P.C.; Powell, P. Coopetition and knowledge-transfer. ACM SIGMIS Database 1999, 30, 14-25. [CrossRef]

22. Bengsston, M.; Kock, S. "Coopetition" in business networks-to cooperate and compete simultaneously. Ind. Mark. Manag. 2000, 29, 411-426.

23. Bengtsson, M.; Eriksson, J.; Wincent, J. Co-opetition dynamics-An outline for further inquiry. Compet. Rev. Int. Bus. J. 2010, 20, 194-214. [CrossRef]

24. Bengsston, M.; Kock, S. Cooperation and competition in relationships between competitors in business networks. J. Bus. Ind. Mark. 1999, 14, 178-194.

25. Soubeyran, A.; Weber, S. District formation and local social capital: A (tacit) co-opetition approach. J. Urban Econ. 2002, 52, 65-92. [CrossRef]

26. BarNir, A.; Smith, K. Interfirm alliances in the small business: The role of social networks. J. Small Bus. Manag. 2002, 40, 219-232. [CrossRef] 
27. Luo, Y. Coopetition in International Business; Copenhagen Business Press: Copenhagen, Denmark, 2004.

28. Slywotzky, A.; Hoban, C. Stop competing yourself to death: Strategic collaboration among rivals. J. Bus. Strategy 2007, 28, 45-55. [CrossRef]

29. Wang, Y.; Krakover, S. Destination marketing: Competition, cooperation or coopetition? Int. J. Contemp. Hosp. Manag. 2008, 20, 126-141. [CrossRef]

30. Gnyawali, D.R.; Park, B.J.R. Co-opetition between giants: Collaboration with competitors for technological innovation. Res. Policy 2011, 40, 650-663. [CrossRef]

31. Ritala, P. Coopetition strategy-When is it successful? Empirical evidence on innovation and market performance. Br. J. Manag. 2012, 23, 307-324.

32. Hsieh, Y.H.; Lin, Y.T.; Yuan, S.T. Expectation-based coopetition approach to service experience design. Simul. Model. Pract. Theory 2013, 34, 64-85. [CrossRef]

33. Park, B.R.; Srivastava, M.K.; Gnyawaly, D.R. Walking the right rope of coopetition: Impact of competition and cooperation intensities and balance of innovation performance. Ind. Mark. Manag. 2014, 43, $210-221$. [CrossRef]

34. Dahal, J. Conceptualizing coopetition as a process: An outline of change in cooperative and competitive interactions. Ind. Mark. Manag. 2014, 43, 272-279. [CrossRef]

35. Pathak, S.D.; Wu, Z.; Johnston, D. Toward a structural view of co-opetition in supply networks. J. Oper. Manag. 2014, 32, 254-267. [CrossRef]

36. Ritala, P.; Golnam, A.; Wegmann, A. Coopetition-based business models: The case of Amazon. Ind. Mark. Manag. 2014, 43, 236-249. [CrossRef]

37. Umachandram, K.; Juricic, I.; Della Corte, V.; Ferdinand-James, D.S. Industry 4.0: The new industrial Revolution. In Big Data Analytics for Smart and Connected Cities; IGI-GLOBAL: Hershey, PA, USA, 2018.

38. Pike, T.; Yang, J.; Roos, G. Is cooperation with competitors a good idea? An example in practice. Br. J. Manag. 2012, 23, 532-560.

39. Easton, G.; Burrell, G.; Rotschild, R.; Shearman, C. Managers and Competition; Routledge: Oxford, UK, 1993.

40. Gnyawali, D.R.; Charleton, T.R. Nuances in the interplay of competition and cooperation: Towards a theory of coopetition. J. Manag. 2018, 44, 2511-2534. [CrossRef]

41. Gomes-Casseres, B. The Alliance Revolution: The New Shape of Business Rivalry; Harvard University Press: Cambridge, MA, USA, 1996.

42. Tani, M.; Papaluca, O.; Sasso, P. The system thinking perspective in the open -innovation research: A systematic review. J. Open Innov. Technol. Mark. Complex. 2018, 4, 38. [CrossRef]

43. Della Corte, V.; Aria, M. Del Gaudio, G. Strategic governance in tourist destinations. Int. J. Tour. Res. 2018, 20,1-13. [CrossRef]

44. Della Corte, V.; Sciarelli, M. Destination Management e Logica Sistemica: Un Confronto Internazionale; Giappichelli: Torino, Italy, 2012.

45. Della Corte, V.; Aria, M. Why strategic networks often fail: Some empirical evidence from the area of Naples. Tour. Manag. 2014, 45, 3-15. [CrossRef]

46. Dyer, J.H.; Singh, H. The Relational View: Cooperative Strategy and Sources of Interorganizational Competitive Advantage. Acad. Manag. Rev. 1998, 23, 660-679. [CrossRef]

47. Čirjevskis, A. Designing dynamically "signature business model" that support durable competitive advantage. J. Open Innov. Technol. Mark. Complex. 2016, 2, 15. [CrossRef]

48. Dubickis, M.; Gaile-Sarkane, E. Transfer know-how based on learning outcomes for development of open innovation. J. Open Innov. Technol. Mark. Complex. 2017, 3, 4. [CrossRef]

49. Umachandran, K.; Ferdinand, D.S.; Jurčić, I.; Della Corte, V. e-commerce: A Social Engagement Tool. J. Econ. Financ. 2017, 8, 60-64.

50. Fong, V.; Wong, I.; Hong, J. Developing institutional logics in the tourism industry through coopetition. Tour. Manag. 2018, 66, 244-262. [CrossRef] 
51. Hosseini, A.S.; Soltani, S.; Mehdizadeh, M. Competitive Advantage and Its Impact on New Product Development Strategy (Case Study: Toos Nirro Technical Firm). J. Open Innov. Technol. Mark. Complex. 2018, 4, 3. [CrossRef]

52. Kodama, F.; Shibata, T. Demand articulation in the open-innovation paradigm. J. Open Innov. Technol. Mark. Complex. 2015, 1, 2. [CrossRef] 